\title{
RECOGNITION AND DISTRIBUTION OF LEPTODACTYLUS MYSTACEUS (ANURA; LEPTODACTYLIDAE) IN THE STATE OF SÃO PAULO, SOUTHEASTERN BRAZIL
}

\author{
Luís Felipe Toledo ${ }^{1,3}$, Luciano Mendes Castanho ${ }^{2}$ \& Célio F. B. Haddad ${ }^{1}$
}

Biota Neotropica v5 (n1) - http://www.biotaneotropica.org.br/v5n1/pt/abstract?article+BN00505012005

Date Received:09/27/2004

Revised: 11/12/2004

Accepted: 01/01/2005

\begin{abstract}
${ }^{1}$ Departamento de Zoologia, Universidade Estadual Paulista, Caixa Postal 199, Rio Claro, São Paulo, CEP 13506-970, Brasil; toledo@rc.unesp.br

${ }^{2}$ Departamento de Morfologia e Patologia, Pontifícia Universidade Católica, Praça Dr. José Ermírio de Moraes, 290, Sorocaba, São Paulo, Lageado, CEP 18030-230, Brazil

${ }^{3}$ corresponding author: LFT: toledo@rc.unesp.br
\end{abstract}

\begin{abstract}
Leptodactylus mystaceus, a widespread species over South America, is diagnosed based on specimens from the State of São Paulo, its southernmost geographic distribution limit. Here we present the first record of this species for Southeastern Brazil, extending its distribution for approximately $1,300 \mathrm{~km}$ to the southeast. We also include a description of its advertisement call, natural history data, photograph in life and morphological illustrations that make easier the identification of the species.
\end{abstract}

Key words: Geographic distribution, advertisement call, Leptodactylus mystaceus.

\section{Resumo}

Leptodactylus mystaceus, uma espécie com ampla distribuição geográfica pela América do Sul, é diagnosticada com base em exemplares do Estado de São Paulo, seu limite meridional de distribuição geográfica. Apresentamos aqui o primeiro registro da espécie para o Sudeste do Brasil, ampliando sua distribuição conhecida em cerca de $1.300 \mathrm{~km}$ ao sudeste. Também incluímos a descrição da vocalização de anúncio, informações sobre história natural, fotografia em vida e desenhos de caracteres morfológicos que auxiliam na identificação desta espécie.

Palavras-chave: Distribuição geográfica, vocalização de anúncio, Leptodactylus mystaceus. 


\section{Introduction}

The genus Leptodactylus Fitzinger includes more than 60 recognized species distributed throughout the Americas (Frost 2004). These species are currently divided into four morphological groups [fuscus (Schneider), melanonotus (Hallowell), ocellatus (Linnaeus), and pentadactylus (Laurenti)], the L. fuscus group being the one that encloses the greatest number of species. After the latest systematic review of the L. fuscus group (Heyer 1978), new species have been added (e.g., Sazima \& Bokermann 1978; Heyer 1983; Heyer et al. 1996) totaling 26 species in the group. One of these species is Leptodactylus mystaceus, which is morphologically identical to L. didymus, differing only on its advertisement calls (see Heyer et al. 1996). Besides L. didymus, L. mystaceus is closely related to other species in the L. fuscus group; but they present a few morphological differences. Here we identify Leptodactylus mystaceus in the State of São Paulo, detail its distribution in the State, expand its geographic distribution range, and review the literature that identify the species inadequately. Furthermore, to help in the identification of L. mystaceus, we present the description of its advertisement call, information about its natural history, and illustrations of some morphological features of a specimen (CFBH 7373) captured in the Municipality of Rio Claro, State of São Paulo, Brazil.

\section{Methods}

Specimens from museum collections in the State of São Paulo, Brazil, were examined and measured with digital caliper of $0.01 \mathrm{~mm}$ of precision. The measurements of the adults follow Cei (1980). Museum abbreviations are: $\mathrm{CFBH}$ for the Célio F. B. Haddad collection, deposited in the Departmento de Zoologia, Unesp, Rio Claro; DZSJRP for the collection of the Departmento de Zoologia, Unesp, São José do Rio Preto; and ZUEC for Museu de História Natural, Unicamp, Campinas.

Observational data on natural history were obtained at the Floresta Estadual Edmundo Navarro de Andrade, Municipality of Rio Claro, São Paulo, between November 2001 and January 2002. The subterranean chambers were found by hand-digging during the search for calling males. Vocalizations were recorded at the same site with a Nagra-E tape recorder and a Sennheiser ME 80 microphone at tape speed of $19 \mathrm{~cm} / \mathrm{s}$. The sound analyses were made in a Macintosh computer, using the Canary 1.2.4 software, configured with 16 bits of resolution, $22 \mathrm{kHz}$ of frequency sampling, FFT and frame length of 256. Drawings of an adult male were made using a stereomicroscope Zeiss SV11.

\section{Results}

Leptodactylus mystaceus is a large-sized species for the L. fuscus group (see Table 1 for measurements of adult specimens collected in the São Paulo State) with brownish dorsal coloration (Fig. 1). The snout is rounded in dorsal view and acuminate in lateral view (Fig. 2). Two pairs of dorsolateral folds. Shoulder blades readily perceptible. Round conspicuous subarticular and supranumeral tubercleson hands and feet (Fig. 2).

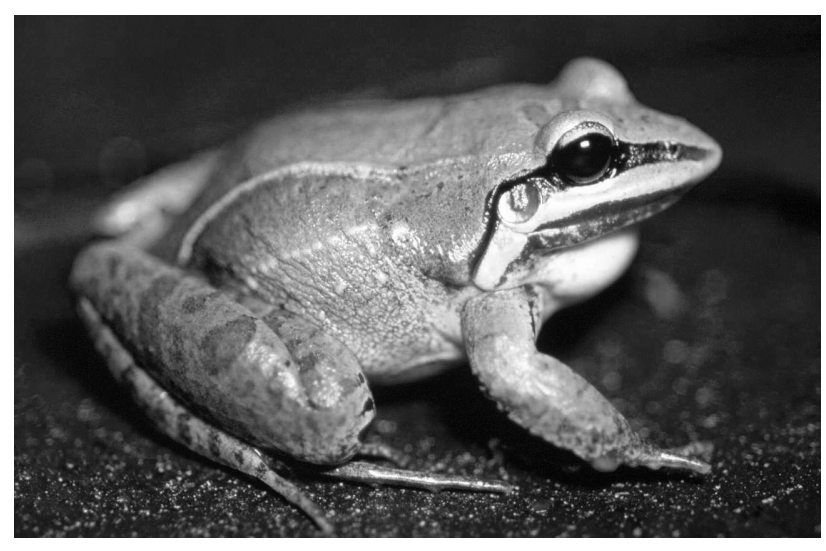

Figure 1. Adult male of Leptodactylus mystaceus in life collected at Floresta Estadual Edmundo Navarro de Andrade, Municipality of Rio Claro, São Paulo, Brazil.

Males of L. mystaceus were observed calling at the onset of the wet and warm season of the year (OctoberNovember) in the open or in the border of forested areas and were syntopic with L. fuscus and L. mystacinus (Toledo et al. 2003). Calling activity began about one hour before sunset and persisted until the middle of the night. Advertisement calls were given frequently, on muddy ground near or inside a subterranean nest. The openings of the nests were about $2.5 \mathrm{~cm}$ wide and $1.5 \mathrm{~cm}$ high. The subterranean elliptic chambers were about $5 \mathrm{~cm}$ deep, $4 \mathrm{~cm}$ wide, and $4 \mathrm{~cm}$ high. Nests were probably dig up by the males and were apparently formed by multiple subterranean connections. These subterranean galleries allowed the frogs to move over $1 \mathrm{~m}$ underground, a tactic that may provide protection against visually hunting predators. The only gravid female collected yielded 379 yellowish ovules accounting for $10.31 \%$ of its body mass.

Each note of the advertisement call of L. mystaceus (Fig. 3) is constituted by a series of about 11 pulses, interspaced by 18-22 ms (Table 2). From the beginning of the sequence, the pulses progressively increase in duration and intensity. However, the last pulse of each sequence is the longest and a little less intense than the precedent pulse. The first pulse has about $10 \mathrm{~ms}$ duration and the latest (the more variable) has from $27-49 \mathrm{~ms}$ duration. The mean duration of the call is about $240 \mathrm{~ms}$ (Table 2). The fundamental frequency ranges $700-1500 \mathrm{~Hz}$, and harmonics may reach $3000 \mathrm{~Hz}$. The frequency gradually increases from the beginning to the end of the note, but the last pulse may present a decreasing frequency modulation (see $2^{\text {nd }}$ note in Fig. 3 ). 


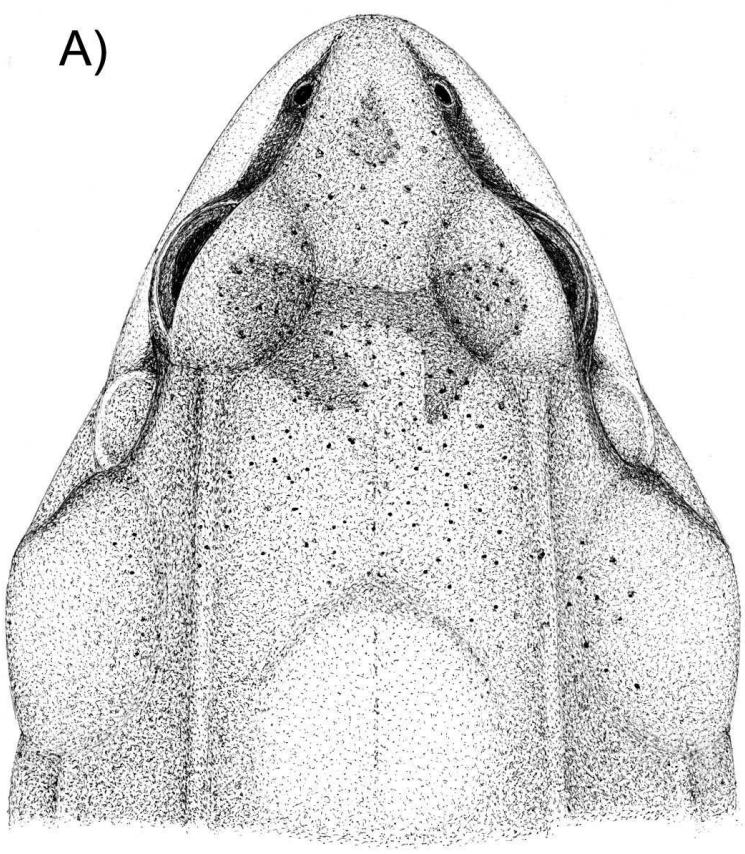

B)

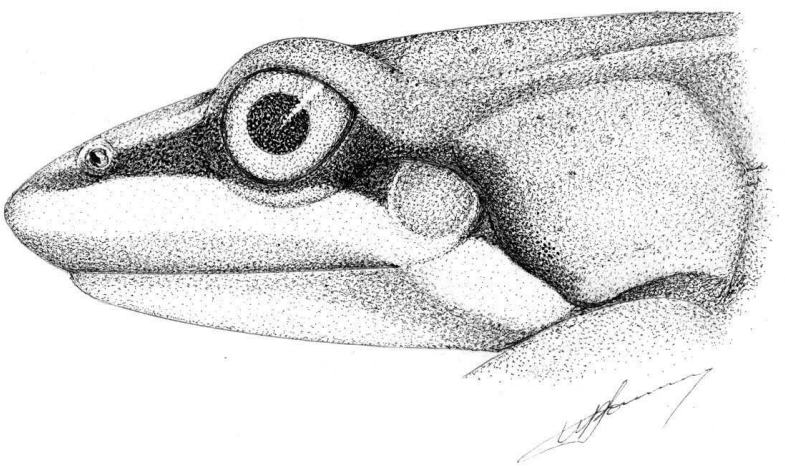

C)
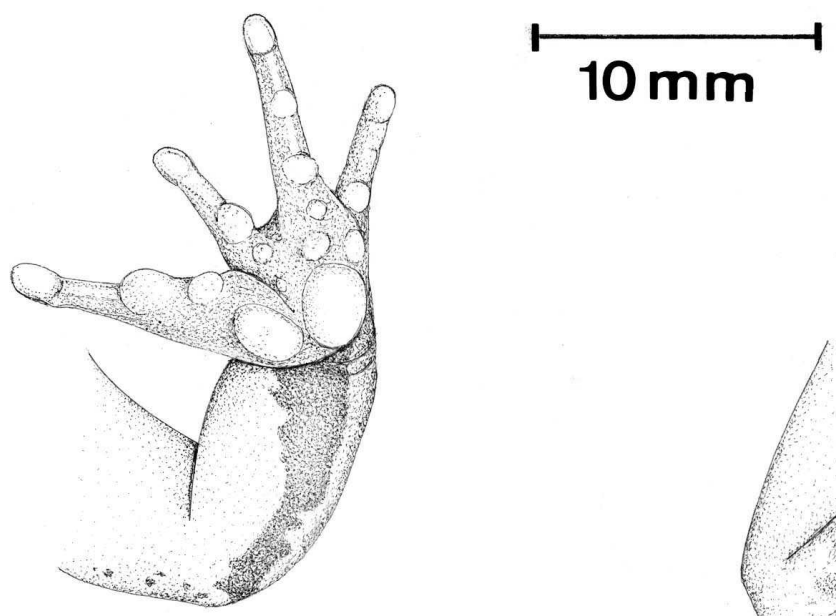

D)

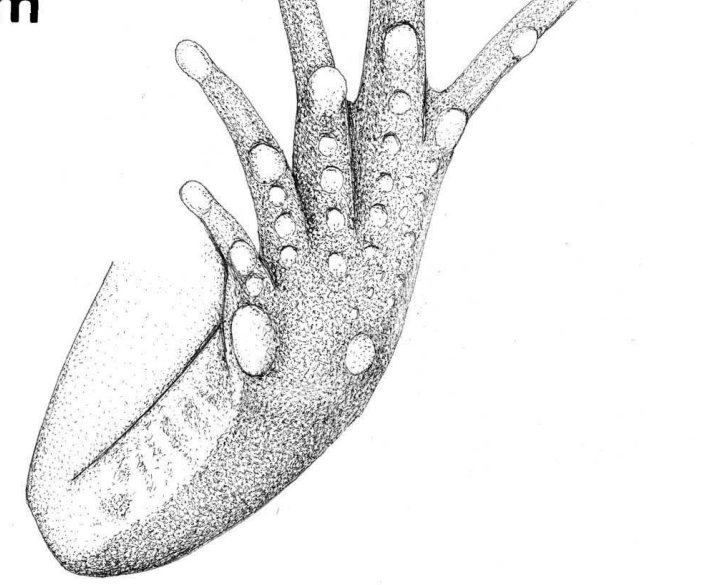

Figure 2. Adult male of Leptodactylus mystaceus (CFBH 7373) collected at Floresta Estadual Edmundo Navarro de Andrade, Municipality of Rio Claro, São Paulo, Brazil. A) dorsal view of the head; B) lateral view of head; C) ventral view of left hand; D) ventral view of left foot. 

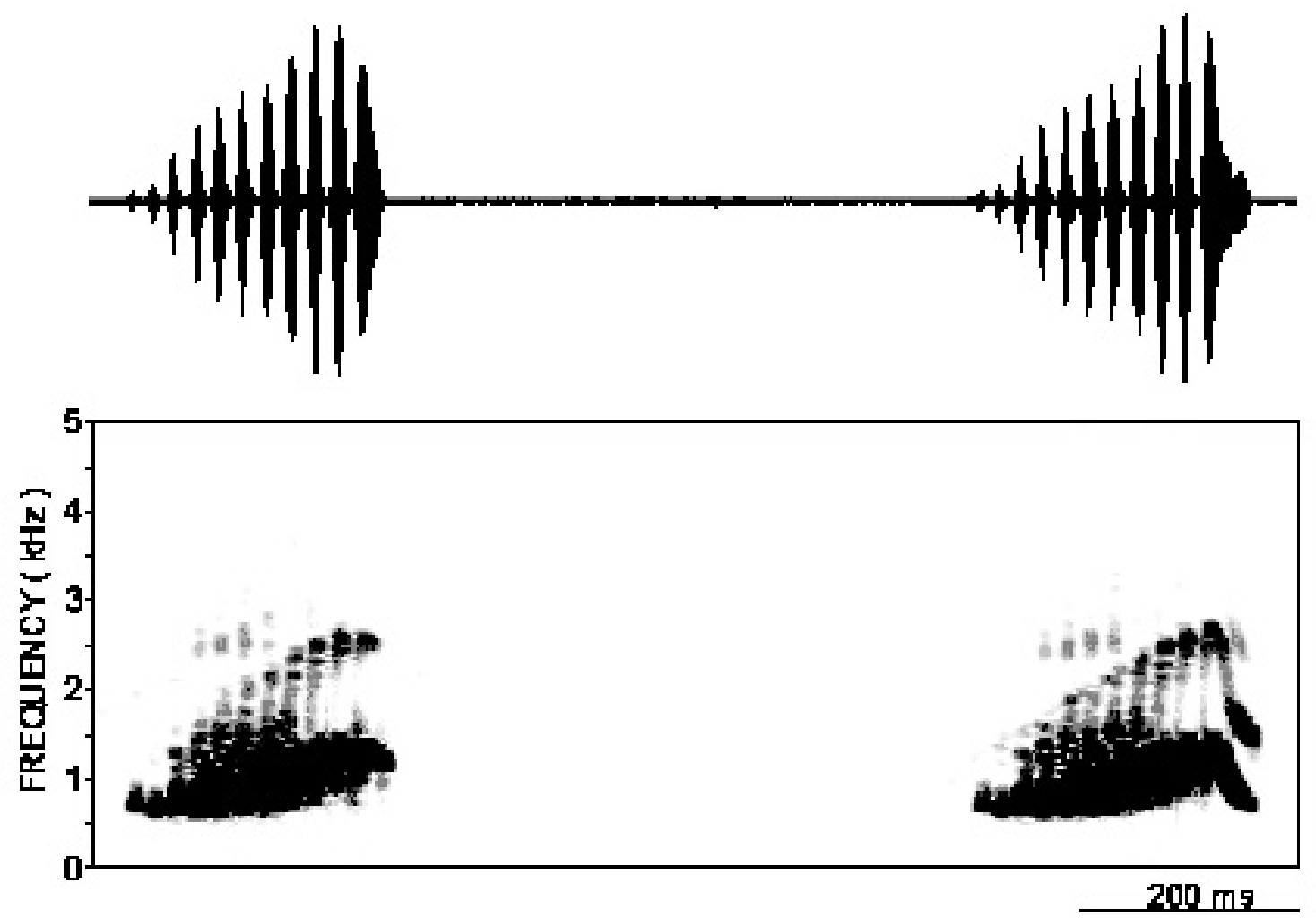

Figure 3. Waveform (upper) and spectrogram (lower) of two notes of the advertisement call of Leptodactylus mystaceus recorded at the Municipality of Rio Claro, São Paulo, Brazil; air temperature $=23^{\circ} \mathrm{C}$.

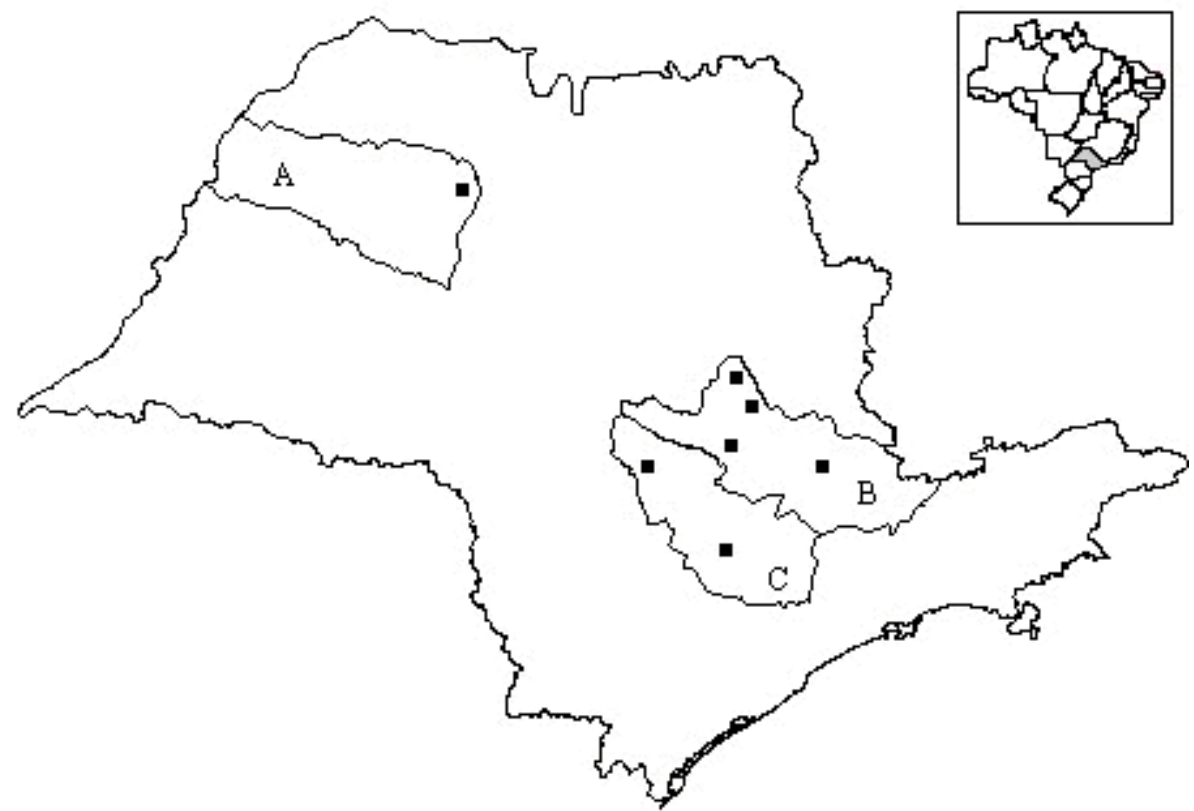

Figure 4. Geographic distribution of Leptodactylus mystaceus in the State of São Paulo, Brazil (dark squares). The limits of the river basins of (A) Baixo Tietê, (B) Piracicaba/Capivari/Jundiai, and (C) Sorocaba/Médio Tietê are also represented. 


\begin{tabular}{lcc}
\hline \hline & $\begin{array}{c}\text { Males } \\
\text { mean (SD; range) }\end{array}$ & Female \\
\cline { 2 - 3 } Snout-vent length & $47.14 \pm 2.49(41.6-51.71)$ & 51.97 \\
Head length & $17.36 \pm 0.87(15.41-19.24)$ & 18.92 \\
Head width & $17.86 \pm 0.84(15.45-18.6)$ & 18.29 \\
Eye diameter & $4.38 \pm 0.38(3.99-5.05)$ & 5.16 \\
Tympanum diameter & $3.01 \pm 0.29(2.54-3.52)$ & 3.01 \\
Interorbital distance & $4.24 \pm 0.42(3.65-4.93)$ & 4.71 \\
Eye to nostril distance & $4.33 \pm 0.24(3.84-4.65)$ & 4.83 \\
Internarial distance & $4.32 \pm 0.22(3.83-4.52)$ & 4.77 \\
Tibia length & $26.25 \pm 1.47(24.15-28.69)$ & 28.51 \\
Thigh length & $23.32 \pm 1.41(21.85-26.45)$ & 26.01 \\
Foot length & $27.27 \pm 1.62(25.23-30.41)$ & 29.62 \\
\hline \hline
\end{tabular}

Table 2. Physical characteristics of the advertisement calls of males of Leptodactylus mystaceus recorded at the Floresta Estadual Edmundo Navarro de Andrade, Municipality of Rio Claro, State of São Paulo, Brazil. Values presented as mean \pm SD (range; $n$ ).

\begin{tabular}{ccccc}
\hline \hline male & note duration $(\mathrm{ms})$ & pulses/note & internote interval & air temp. $\left({ }^{\circ} \mathrm{C}\right)$ \\
\hline \multirow{2}{*}{1} & $249.0 \pm 8.6$ & $12.0 \pm 0.0$ & $684.4 \pm 193.3$ & 23 \\
& $(236-262 ; 20)$ & $(12-12 ; 20)$ & $(472-1185 ; 18)$ & \\
2 & $220.9 \pm 4.3$ & $10.9 \pm 0.2$ & $721.2 \pm 415.6$ & 23 \\
& $(215-229 ; 20)$ & $(10-11 ; 20)$ & $(431-2108 ; 19)$ & \\
3 & $247.2 \pm 5.7$ & $11.5 \pm 0.5$ & $540.6 \pm 143.9$ & 23 \\
& $(234-259 ; 31)$ & $(11-12 ; 31)$ & $(423-1001 ; 19)$ & \\
\hline \hline
\end{tabular}

\section{Discussion}

Several authors were unable to identify L. mystaceus as such in the State of São Paulo, treating it as Leptodactylus notoakitites (Jim, 1980; Silva et al. 2000), Leptodactylus sp. (Rossa-Feres \& Jim, 1994), and Leptodactylus sp. (gr. fuscus) (Toledo et al. 2003). The difficulty in identifying L. mystaceus is due to its very similar morphology with L. dydimus (so called cryptic species) and a strong resemblance with $L$. notoakitites (except for the presence of scattered white supranumeraries tubercles on sole of foot, not often observed in L. notoakitites), the advertisement call being the most remarkable difference between these three species.

While examining specimens deposited in museum collections and recordings of their advertisement calls (which agreed with the call descriptions provided by Heyer et al.
1996) we collected data from six municipalities in the State of São Paulo where L. mystaceus occurs: Rio Claro (CFBH 4535, 5487, 6002; 7362-73), Corumbataí (CFBH 931; DZSJRP 566364), Piracicaba (CFBH 3828), Campinas (ZUEC 6890), José Bonifácio (CFBH 5998), and Araçoiaba da Serra (CFBH 59996001 ) (see Fig. 4). Among them, Araçoiaba da Serra (2330' S; $47^{\circ} 36^{\prime} \mathrm{W}$ ) is now the southernmost limit of the species, extending its distribution range approximately $1,300 \mathrm{~km}$ southeastern from the Chapada dos Guimarães (1530' S; 56 $06^{\circ}$ ' W), Municipality of Cuiabá, State of Mato Grosso, Western Brazil, which was previously the southernmost known limit of its distribution based on animals with recorded advertisement calls (see Heyer et al. 1996). The population of the Municipality of Uberlândia (18 $55^{\prime}$ S; $48^{\circ} 16^{\prime}$ W), State of Minas Gerais (as L. amazonicus in Heyer 1978), which is about $515 \mathrm{~km}$ from the 
southern distribution of L. mystaceus (present study), had no advertisement calls reported; however, we believe that the population of Minas Gerais is actually composed of $L$. mystaceus rather than L. dydimus, which seems to be restrict to the Amazon basin (Heyer et al. 1996).

\section{Acknowledgments}

We are gratefully to Luciana Lugli and Juliana Zina that helped on field; Two anonymous referees for revising the manuscript; Denise Rossa-Feres for providing the access to the specimens deposited at DZSJRP; Jaime Somera who made the line drawings; and Fundação O Boticário de Proteção à Natureza, CNPq, and BIOTA-FAPESP (proc. 01/ 13341-3) for granting the Herpetology lab.

\section{References}

CEI, J. M. 1980. Amphibians of Argentina. Monitore Zoologico Italaliano, (N.S.) Monografia 2:i-xii, 1-609.

FROST, D. R. 2004. Amphibian species of the world: an online reference. Version 3.0 (22 August, 2004). Eletronic database accessible at: $<$ http://research.amnh.org/herpetology/amphibia/index.html>.

HEYER, R. W. 1978. Systematics of the fuscus group of the genus Leptodactylus (Amphibia, Leptodactylidae). Natural History Museum of Los Angeles County Science Bulletin, 29, 1-85.

HEYER, R. W. 1983. Clarification of the names Rana mystacea Spix, 1824, Leptodactylus amazonicus Heyer, 1978 and a description of a new species, Leptodactylus spixii (Amphibia: Leptodactylidae). Proceedings of the Biological Society of Washington, 96(2), 270-272.

HEYER, R.W., GARCÍA-LOPEZ, J.M. \& CARDOSO, A.J. 1996. Advertisement call variation in the Leptodactylus mystaceus species complex (Amphibia: Leptodactylidae) with a description of a new sibling species. AmphibiaReptilia, 1996(17), 7-31.

JIM, J. 1980. Aspectos ecológicos dos anfíbios registrados na região de Botucatu, São Paulo (Amphibia, Anura). Tese de doutorado, Universidade de São Paulo, São Paulo.

ROSSA-FERES, D.C. \& JIM, J. 1994. Distribuição sazonal em comunidades de anfíbios anuros na região neotropical de Botucatu, São Paulo. Revista Brasileira de Biologia, 54(2): 323-334.

SAZIMA, I. \& BOKERMANN, W.C.A. 1978. Cinco novas espécies de Leptodactylus do centro e sudeste do brasileiro (Amphibia, Anura, Leptodactylidae). Revista Brasileira de Biologia, 38(4), 899-912.

SILVA, A.P.Z., HADDAD, C.F.B. \& KASAHARA, S. 2000. Chromosomal studies on five species of the genus Leptodactylus Fitzinger, 1826 (Amphibia, Anura) using differential staining. Cytobios, 103, 25-38.
TOLEDO, L.F., ZINA, J. \& HADDAD, C.F.B. 2003. Distribuição especial e temporal de uma comunidade de anfíbios anuros do Município de Rio Claro, São Paulo, Brasil. Holos Environmet, 3(2), 136-149.
Title: Recognition and distribution of Leptodactylus mystaceus (Anura; Leptodactylidae) in the State of São Paulo, Southeastern Brazil

Authors: Luís Felipe Toledo, Luciano Mendes Castanho \& Célio F. B. Haddad

Biota Neotropica, Vol. 5 ( number 1): 2005

http://www.biotaneotropica.org.br/v 5n 1/pt/ abstract?article+BN00505012005

Recebido: 27/09/2004

Revisado: 12/11/2004

Publicado: 01/01/2005

ISSN 1676-0611 